\title{
THE COMMUNIST MANIFESTO, 170 YEARS LATER
}

Abstract: No text written in the mid-nineteenth century has held the road until today as well as the Communist Manifesto of 1848. Even today entire paragraphs of the text correspond to the contemporary reality even better than in 1848. Starting from the premises which were hardly visible in the era, Marx and Engels drew the conclusions which the deployment of 170 years of history fully consolidated. In this article I will give further enlightening examples.

Keywords:: historical materialism, revolution, decadence; globalisation, homogenization, polarisation; imperialism; capitalist parenthesis in history; bourgeois democratic revolution, popular democratic revolution.

1.

There is no any other text written in the middle of the Nineteenth century which retained validity until this day as well as the Manifesto of the Communist Party. Even today entire paragraphs of the text correspond to the contemporary reality even better than in 1848. Starting from the premises which were hardly visible in the era, Marx and Engels drew the conclusions which the deployment of 170 years of history fully consolidated. In this article I will give further enlightening examples.

Were Marx and Engels inspired prophets, magicians able to read in a crystal ball, exceptional beings in respect of their intuition? No. They have only better understood than anybody else, in their time and for our time still, the essence of that which defines and characterizes capitalism. Marx has devoted his entire life to deepen this analysis through the double examination of the new economy (starting from the example of England) and of the new politics (starting from the example of France).I wrote about this subject in $O c$ tober 1917 Revolution, a century later (Amin, 2017, p. 41)2.

Marx's major work-Capital-presents a rigorous scientific analysis of the capitalist mode of production and capitalist society and how they differ from earlier society forms. Volume 1 delves into the heart of the problem. It directly clarifies the meaning of the generalization of commodity exchanges between private property owners (and this char-

1 samir.amin@wanadoo.fr

2 In chapter three, "Reading Capital". 
acteristic is unique to the modern world of capitalism, even if commodity exchanges had existed earlier), specifically the emergence and dominance of value and abstract social labour. From that foundation, Marx leads us to understand how the proletarian's sale of his or her labour power to the "man with money" ensures the production of surplus value that the capitalist expropriates, and which, in turn, is the condition for the accumulation of capital. The dominance of value governs not only the reproduction of the economic system of capitalism; it governs every aspect of modern social and political life. The concept of commodity alienation points to the ideological mechanism through which the overall unity of social reproduction is expressed.

The intellectual and political instrument, confirmed by the development of « Marxism ", demonstrated itself to be the best for predicting in a correct way the general line of the historical evolution of the capitalist reality. No attempt to think this reality outside of Marxism - or often against it- had lead to comparable results. The mistake of the bourgeois thought and in particular of its «economic science» (described by Marx with good reason as «vulgar») is masterful. Since it is incapable to understand what capitalism is in its essential reality, this alienated thought is also not able to imagine where the capitalist societies are going. Will the future be forged by socialist revolutions which will put an end to the domination of capital? Or will capitalism succeed to prolong its days, opening thus the way to decadence of society? Bourgeois thought ignores this question, posed by the Manifesto.

Indeed we read in Manifesto (Marx, 1995, p. 7):

"... a war which always ends by a revolutionary transformation of the society, of by destruction of the two classes in conflict. "

This sentence has attracted my attention since long time. Starting from it I have progressively come to formulate a reading of the movement of history focused on the concept of unequal development and possible different processes for its transformation starting most probably from its peripheries rather than from its centres. I also made some attempts to clarify the meaning of each of the two models of response to the challenge: the revolutionary way and the way of decadence.

I have further written about this question in the book "Class and Nation " (Amin, 1979, pp 250-252; 254-255).

Choosing to derive the laws of historical materialism from the universal experience, we have proposed an alternative formulation of one unique pre capitalist mode, the tributary mode, toward which all class societies tend. The history of the West - the construction of Roman antiquity, its disintegration, the establishment of feudal Europe, and, finally, the crystallization of absolutist states of the mercantilist era - thus expresses in a particular form the same basic tendency which elsewhere is expressed in the less discontinuous construction of complete, tributary states, of which China is the strongest expression. The slave mode is not universal in our reading of history, as are the tributary and capitalist modes; it is particular and appears strictly in connection with the extension of commodity relations. In addition, the feudal mode is the primitive, incomplete form of the tributary mode. .

This hypothesis views the establishment and subsequent disintegration of Rome, as a premature attempt at tributary construction. The level of development of the productive

\footnotetext{
3 Chapter "Revolution or decadence".
} 
forces did not require tributary centralization on the scale of the Roman Empire. This first abortive attempt was thus followed by a forced transition through feudal fragmentation, on the basis of which centralization was once again restored within the framework of the absolutist monarchies of the West. Only then did the mode of production in the West approach the complete tributary model. It was, furthermore, only beginning with this stage that the level of development of the productive forces in the West attained that of the complete tributary mode of imperial China; this is doubtless no coincidence.

The backwardness of the West, expressed by the abortion of Rome and by feudal fragmentation, certainly gave it its historic advantage. Indeed, the combination of specific elements of the ancient tributary mode and of barbarian communal modes characterized feudalism and gave the West its flexibility. This explains the speed with which Europe passed through the complete tributary phase, quickly surpassing the level of development of the productive forces of the East, which it overtook, and passing on to capitalism. This flexibility and speed contrasted with the relatively rigid and slow evolution of the complete tributary modes of the Orient.

Doubtless the Roman-Western case is not the only example of an abortive tributary construction. We can identify at least three other cases of this type, each with its own specific conditions: the Byzantine-Arab-Ottoman case, the Indian case, the Mongol case. In each of these instances, attempts to install tributary systems of centralization were too far ahead of the requirements of the development of the productive forces to be firmly established. In each case the forms of centralization were probably specific combinations of state, para feudal, and commodity means. In the Islamic state, for instance, commodity centralization played the decisive role. Successive Indian failures must be related to the contents of Hindu ideology, which I have contrasted with Confucianism. As to the centralization of the empire of Genghis Khan, it was, as we know, extremely short-lived.

The contemporary imperialist system is also a system of centralization of the surplus on the world scale. This centralization operated on the basis of the fundamental laws of the capitalist mode and in the conditions of its domination over the pre capitalist modes of the subject periphery. I have formulated the law of the accumulation of capital on the world scale as a form of expression of the law of value operating on this scale. The imperialist system for the centralization of value is characterized by the acceleration of accumulation and by the development of the productive forces in the centre of the system, while in the periphery these latter are held back and deformed. Development and underdevelopment are two sides of the same coin.

Only people make their own history. Neither animals nor inanimate objects control their own evolution; they are subject to it. The concept of praxis is proper to society, as expression of the synthesis of determinism and human intervention. The dialectic relation of infrastructure and superstructure is also proper to society and has no equivalent in nature. This relation is not unilateral. The superstructure is not the reflection of the needs of the infrastructure. If this was the case, society would be always alienated and it would not be possible to see how it could succeed to liberate itself.

This is the reason for which we propose to differentiate two qualitatively different types of transition from one mode of production to another. If this transition envelops in unconsciousness, or with alienated consciousness, that is if ideology which influences classes does not allow them to control the process of change, this process appears as if it 
operates in the way analogous to natural change, while ideology becomes part of this nature. For this type of transition we reserve the expression « model of decadence ».On the other hand, if ideology manages to offer total and real dimension of the desired change, and only then, we can speak of revolution.

The bourgeois thought has to ignore this question in order to be able to think of capitalism as a rational system for entire future time, to be able to think « the end of history ».

\section{2.}

Marx and Engels, on the contrary, strongly suggest - from the time of the Manifesto - that capitalism constitutes only a brief parenthesis in the history of humanity. However the capitalist mode of production in their time did not surpass England, Belgium and a small region of northern France as well as the western part of the Prussian Westphalia. In other regions of entire Europe nothing comparable did exist. In spite of this, Marx already imagined that socialist revolutions will happen in Europe "soon". This expectation transpires from each line of the Manifesto.

Marx did not know of course from which country the revolution will begin. England, the only country already advanced in capitalism ? No. Marx did not think this was possible except if the English proletariat emancipated itself from its alignment to the support to the colonization of Ireland. France, less advanced in terms of its capitalist development, but more in terms of political maturity of its people, inherited from its Great revolution? Maybe, The Paris Commune (1871) has confirmed his intuition. For the same reason Engels expected much from "backward" Germany: the proletarian revolution and the bourgeois revolution could here collide together. The Manifesto writes in this connection (Marx, 1995, p. 54) the following:

"The Communists turn their attention chiefly to Germany, because that country is on the eve of a bourgeois revolution that is bound to be carried out under more advanced conditions of European civilization and with a much more developed proletariat than that of England was in the seventeenth, and France in the eighteenth century, and because the bourgeois revolution in Germany will be but the prelude to an immediately following proletarian revolution».

This did not happen: the unification under the crook of reactionary Prussia, the political mediocrity of the German bourgeoisie and its cowardice permitted that nationalism triumphs and marginalizes popular revolt. Marx turned his glance towards the end of his life in the direction of Russia, which he expected could engage on a revolutionary path, as his correspondence with Vera Zassoulitch testifies.

Marx thus did have the intuition that the revolutionary transformation could begin starting from the periphery of the system - the " weak links » " in the ulterior language of Lenin. Marx, however, did not draw in his time all the conclusions which imposed themselves in this respect. It was necessary to wait that the history advances into the XXth century, in order to see, with Lenin and Mao, the communists becoming able to imagine a new strategy qualified as " the construction of socialism in one country ". This is an inappropriate expression, to which I prefer a long periphrasis: "unequal advances on the long path of the socialist transition, localized in some countries which the strategy of dominant imperialism isolates and fights continuously and severely". 
The debate pertaining to this problem related to the long historic transition to socialism in direction of communism and to the universal scope of this movement poses a series of questions concerning the transformation of the proletariat from the class in itself to the class for itself, the conditions and effects of capitalist globalization, the place of the peasantry in the long transition, the diversity of expressions of the anti-capitalist thought, all questions which I address in the following section.

\section{3.}

Marx, more than anyone, understood that capitalism had the mission to conquer the world. He wrote about it at a time when this conquest was far from being completed. He considered this mission from its origins, the discovery of the Americas which inaugurated the transition of the three centuries of mercantilism to the final full- fledged form of capitalism.

He wrote in the Manifesto:

"Modern industry has established the world market, for which the discovery of America paved the way...through exploitation of the world market it has given a cosmopolitan character to production and consumption of each country» (Marx, 1995, p. 11).

Marx welcomed this globalization, the new phenomenon in the history of humanity. Numerous passages in the Manifesto testify to this. .For example:

"The bourgeoisie, wherever it has got the upper hand, has put an end to all feudal, patriarchal, idyllic relations ... " (Marx, 1995, p. 10).

And:

"The bourgeoisie has subjected the country to the rule of the towns ... and has thus rescued a considerable part of the population from the idiocy of rural life ... as it has made the country dependent on the towns, so it has made barbarian and semi-barbarian countries dependent on the civilized ones, nations of peasants on nations of bourgeois, the East on the West ...» (Marx, 1995, p. 13).

Words are clear. Marx has never been past oriented, regretting the "good old days". He always expressed a modern point of view, to the point of appearing as a Euro centrist. He went a long way in this direction. Yet was not the barbarization of the village labour replaced with the urban labour not less stultifying for the proletarians? Marx does not ignore the urban poverty which had accompanied capitalist expansion.

Has Marx of the Manifesto measured correctly the political consequences of the destruction of the peasantry, in Europe itself, and even more, in the colonized countries? I return to these questions in direct relation with the unequal character of the worldwide deployment of capitalism.

Marx and Engels, in the Manifesto, still do not know that the worldwide deployment of capitalism is not the one which they imagined, homogenizing, that is, giving to the conquered East its chance to get out of the dead lock in which its history has closed it and to become, in accordance with the image of the Western countries, "civilized » nations, that is, industrialized countries. Few later texts of Marx present the colonization of India in consoling light. But Marx later changed his mind. These allusions, rather than a systematically elaborated argumentation, witness about the destructive effects of the colonial conquering. Marx gradually becomes aware of what I call «unequal development», i.e. 
systematic construction of the contrast between the dominant centres and dominated peripheries, and, with it, the impossibility to « catch up» within the framework of capitalist globalization (in fact imperialistic by its nature), and with the tools of capitalism.

In that respect I said that if it were possible to «catch up » within capitalist globalization, no political, social or ideological force would be able to oppose it successfully.

With respect to the question of the "opening" of China, Marx of the Manifesto says:

"The cheap prices of commodities are the heavy artillery with which it batters down all Chinese walls, with which it forces the barbarians' intensely obstinate hatred of foreigners to capitulate» (Marx, 1995, p. 12)..

We know that this was not how this opening operated: it was the canons of the British navy which "opened" China. Chinese products were often more competitive than western. We know also that it was not English more advanced industry that permitted the successful domination of India (again Indian textiles were of better quality than English). On the contrary, it was the domination of India (and the organized destruction of Indian industries) which gave to Great Britain its hegemonic position in the capitalist system of the XIX th century.

However, older Marx learned how to abandon the Euro centrism of his youth. Marx knew how to change his opinion, in the light of the evolution of the world.

In 1848 Marx and Engels therefore imagined the strong possibility of one or more socialist revolutions in Europe of their time, confirming with this that capitalism represents only a short parenthesis in history. The facts soon proved him right. The Paris Commune (1871) was the first socialist revolution. However, it was as well the last revolution accomplished in a developed capitalist country. With the establishment of the Second Internationale Engels did not lose the hope in new revolutionary advances, in Germany in particular. History proved him wrong. However the treason of the Second Internationale in 1914 should not have surprised anyone. Beyond their reformist drift, alignment of workers' parties of entire Europe of the time with the expansionistic imperialist and colonial politics of their bourgeoisies indicated that there was not much to expect from for the parties of the Second Internationale. The front line for the transformation of the world moved towards the East, to Russia in 1917 and then to China. Certainly Marx did not « predict » this; but his later texts allow us to suppose that he probably would not have been surprised by the Russian revolution.

On the other hand, Marx thought, with respect to China, that it was the bourgeois revolution which was on the agenda. After the intervention of European forces in response to the rebellion of the Boxers, he reminded that next time when European armies will try to enter China, they will be stunned with the front board on which they will read: «Attention, you are entering into the Bourgeois Republic of China! ». The Kuo Min Tang of the 1911 revolution, of Sun Yat Sen, has also imagined, like Marx, proclaiming the (bourgeois) Republic of China. However, Sun did not succeed neither to defeat the forces of the old regime whose war-lords regained the territory, nor to push away the dominance of the imperialist forces, especially of Japan. The drift of the KMT of Tchang Kai-chek, confirmed Lenin's and Mao's points of view: there is no more place for an authentic bourgeois revolution, our era is the one of the socialist revolution. Just as the Russian February revolution of 1917 did not have future, since it was not able to triumph over the old regime calling therefore for the October revolution, the Chinese revolution of the 1911 called for the 
revolution of the Maoist communists, only capable to answer to the expectations of liberation which is simultaneously national and social.

It was thus Russia, the "weak link » of the system, which initiated the second socialist revolution after the Paris Commune. Yet the Russian October was not supported, but fought by the European workers' movement. Rosa Luxembourg used harsh expressions for the drifts of the European workers movements. She speaks of their «deficiency ", of " the incapacity of the German proletariat to realize its historic mission», of «treason " (Luxemburg, 2017, pp. 10, 59).

I have for my part proposed the analysis of this withdrawal of the working class in the developed West, abandoning their revolutionary traditions of the XIXth century, by putting the accent on the devastating effects of the imperialistic character of the worldwide expansion of capitalism and of the benefits which the entirety of the concerned societies (and not only their bourgeoisies) draw from their dominant positions. I have therefore considered it necessary, to dedicate an entire chapter within my reading of the universal importance of the 1917 October Revolution (Amin, 2017) ${ }^{4}$, to the analysis of the development which had lead the European working classes to renounce their historic mission, expressed in terms of Rosa Luxemburg. I refer the reader to this text.

\section{4.}

Revolutionary advances on the long road of the socialist or communist transition will therefore probably start exclusively in the societies of the periphery of the world system, precisely in the countries in which an avant-garde would understand that it is not possible to " catch up » by integrating into capitalist globalization, and that for this reason « something else should be done ", that is, go ahead within a transition of socialist nature. Lenin and Mao have expressed this conviction proclaiming that our time is not any more the epoch of bourgeois revolutions but that it is from then on the epoch of the socialist revolutions.

This conclusion calls for another: socialist transitions will happen necessarily « in one country ", which will additionally remain fatally " isolated » through the counter-attack of world imperialism. There is no alternative; there will be no " world revolution». Therefore the nations and states engaged on this road will be confronted with the double challenge: resist to the permanent war (hot or cold) conducted by the imperialist forces, and associate successfully the peasant majority in the advances on the new road to socialism. Neither the Manifesto, not even Marx and Engels subsequently had been in position to tell something on these questions. It belongs to the living Marxism to do this instead of them.

These reflections lead me to assess the considerations which Marx and Engels developed in the Manifesto concerning the peasants. Marx situates himself within his time which was still the time of bourgeois unfinished revolutions in Europe itself. In this context we read in the Manifesto:

"At this stage, therefore, the proletarians do not fight their enemies, but the enemy of their enemies, the remnants of absolute monarchy, the landowners...every victory so obtained is a victory for the bourgeoisie».(Marx, 1995, p. 18).

But the bourgeois revolution gave the land to the peasants as shown in the exemplary case of France in particular. Therefore the peasantry in its great majority becomes the

${ }^{4}$ Chapter four "Revolutions and counter revolutions from 1917 to 2017" 
ally of the bourgeoisie within the camp of the defenders of the sacred character of private property and becomes the adversary of the proletariat.

However, the transfer of the centre of gravity of the socialist transformation of the world, emigrating from dominant imperialist centers to dominated peripheries radically modifies the peasant question. Nevertheless revolutionary advances become possible in the conditions of societies which remained still in great part peasant only if socialist vanguards are able to implement strategies which integrate the majority of peasantry within the fighting block against imperialistic capitalism.

\section{5.}

Marx and Engels never believed, neither for the editing of the Manifesto nor later, in the spontaneous revolutionary potential of the working classes, since " The ruling ideas of each age have ever been the ideas of its ruling class " (Marx, 1995, p. 34). Due to this fact the workers like others subscribe to the ideology of " competition ", corner stone for the functioning of the capitalist society, and, hence, " the organisation of the proletarians into a class, and, consequently into a political party, is continually being upset again by the competition between the workers themselves" (Marx, 1995, p. 20).

Therefore the transformation of the proletariat from the class in itself into the class for itself implicates the active intervention of a communist vanguard : "practically, the most advanced and resolute section of the working-class parties of every country, that section which pushes forward all others; on the other hand, theoretically, they have over the great mass of the proletariat the advantage of clearly understanding the line of march, the conditions, and the ultimate general results of the proletarian movement.» (Marx, 1995, p. 25).

The affirmation of the unavoidable role of the vanguards does not mean for Marx an advocacy in favour of the « single party ». One reads in the Manifesto:

"The Communists do not form a separate party opposed to the other working-class parties...They do not set up any sectarian principles of their own, by which to shape and mould the proletarian movement» (Marx, 1995, p. 25).

And later in his conception of what should be a Proletarian Internationale, Marx considered it necessary to integrate into it all the parties and current of thought and action which benefit from a real popular and worker audience. The First Internationale included in its membership the French Blanquists, the German Lassalians, English trade-unionists, Proudhon, anarchists, Bakounin. Marx certainly did not spare his criticisms, often harsh, for many of his partners. And one might say that probably the violence of these conflictual debates is at the root of the brief life of this Internationale. Let it be as it may. This organisation has nevertheless been the first school for the education of the future cadres engaged in the fight against capitalism.

Two observations lead to the question of the role of the party and the communists.

The first is related to the relationship between the communist movement and the " nation ». We can read in the Manifesto:

"The working men have no country. We cannot take from them what they have not got. Since the proletariat must first of all acquire political supremacy, must rise to be the leading class of the nation, must constitute itself the nation, it is so far, itself national, though not in the bourgeois sense of the word. ", "The fight of the proletariat against the 
bourgeoisie, even though it is not in its basis national, takes up however a national form" (Marx, 1995, p. 33).

In the capitalist world the proletarians do not share the nationalism, of their country; they do not belong to that nation. The reason is that in the bourgeois world the only function of nationalism is to give legitimacy on the one side to the exploitation of workers of the given country and on the other hand to the fight of the bourgeoisie against its foreign competitors and fulfil its imperialistic ambitions. However with the triumph of eventual socialist revolution, all would change. What I said above concerns the first long stages of the socialist transition in the societies of the peripheries. It also expresses the respect for the necessary diversity of the roads taken. Additionally the concept of the final objective of communism, strengthens the importance of this national diversity of the proletarian nations. The Manifesto already formulated the idea that communism is built on diversity of individuals, collectives and nations. Solidarity does exclude but implies free development of all. Communism is the antithesis of capitalism which, in spite of its advocating "individualism", produces in fact, through competition clones formatted by the domination of capital.

I will proceed now by citing in this connection that which I have wrote in the «October 1917 Revolution, a century later " (Amin, 2017, pp 83-85):

"The support or the rejection of national sovereignty gives rise to severe misunderstandings as long as the class content of the strategy in the frame of which it operates is not identified. The dominant social bloc in capitalist societies always conceives national sovereignty as an instrument to promote its class interests, i.e. the capitalist exploitation of home labour and simultaneously the consolidation of its position in the global system. Today, in the context of the globalized liberal system dominated by the financialized monopolies of the Triad (USA, Europe, Japan) national sovereignty is the instrument which permits ruling classes to maintain their competitive positions within the system. The government of the USA offers the clearest example of that constant practice: sovereignty is conceived as the exclusive preserve of US monopoly capital and to that effect the US national law is given priority above international law. That was also the practice of the European imperialist powers in the past and it continues to be the practice of the major European states within the European Union"5.

Keeping that in mind, one understands why the national discourse in praise of the virtues of sovereignty hiding the class interests in the service of which it operates has always been unacceptable for all those who defend the labouring classes.

Yet we should not reduce the defence of sovereignty to that modality of bourgeois nationalism. The defence of sovereignty is no less decisive for the protection of the popular alternative on the long road to socialism. It even constitutes an inescapable condition for advances in that direction. The reason is that the global order (as well as its sub-global European order) will never be transformed from above through collective decisions of the ruling classes. Progress in that respect is always the result of the unequal advance of struggles from one country to another. The transformation of the global system (or the subsystem of the European Union) is the product of those changes operating within the frame of the various states which, in their turn, modifies the international balances of forces between them. The nation state remains the only frame for the deployment of the decisive struggles which ultimately transform the world.

${ }^{5}$ I have discussed this question specific to Europe in The implosion of contemporary capitalism (Amin, 2013), chapter 4 "Implosion of the European System". 
The peoples of the peripheries of that system, polarising by nature, have a long experience of that positive progressive nationalism which is anti-imperialist, rejects the global order imposed by the centres, and therefore is potentially anti-capitalist. I say only potentially because this nationalism may also inspire the illusion of a possible building of a national capitalist order able to catch up with the national capitalisms ruling the centres. Nationalism in the peripheries is progressive only at that condition, as long as it remains anti-imperialist, i.e. today conflicting with the global liberal order. Any other nationalism (which in this case is only a façade) which accepts the global liberal order is the instrument of local ruling classes aiming at participating in the exploitation of their peoples and eventually of other weaker partners, operating therefore as sub-imperialist powers.

The confusion between these two antonymic concepts of national sovereignty and therefore the rejection of any nationalism annihilates the possibility of moving out of the global liberal order. Unfortunately, the left-in Europe and elsewhere-does often make such a confusion".

The second point concerns the segmentation of the working classes, in spite of the « simplification of the society connected with the advancement of capitalism, evocated in the Manifesto page 7 :

"Our epoch, the epoch of the bourgeoisie, possesses, however, this distinct feature: it has simplified class antagonisms. Society as a whole is more and more splitting up into two great hostile camps, into two great classes directly facing each other - Bourgeoisie and Proletariat» (Marx, 1995, p.7).

This double movement - of the generalisation of the proletarian position and simultaneously the segmentation of the world of workers -is today considerably more visible than it was in 1848, when it barely was appearing.

We have witnessed during the prolonged XXth century, up to our days a generalisation without precedent of the proletarian condition. Today in centres almost totality of the population is reduced to the status of employees selling their working force. And in the peripheries the peasants are integrated more then ever before within commercial nets which have annihilated their status of independent producers to make them dominated subcontractors, reduced in fact to the status of sellers of their labor force.

This movement is associated with pauperization processes. "The worker falls into pauperization and impoverishment increases faster than population and wealth (Marx, 1995, p. 23). This pauperisation thesis, retaken and amplified in Capital, was the object of sarcastic critics of the vulgar economists. And still, at the level of the world capitalist system, the only level which gives the full sense to the analysis of the reality, this pauperisation is considerably more visible and real than Marx had imagined. However, and in parallel, the capitalist forces have succeeded to weaken the danger which generalised poletarianisation represented by implementing systematic strategies aiming at segmenting the working classes on all levels, from national to international.

6.

The section III of the Manifesto, entitled « Socialist and communist literature » could appear to a contemporary reader to belong truly to the past. Marx and Engels offer us here commentaries concerning historical subjects and their intellectual production which 
belong to their time. Forgotten, these questions seem to day to be the subject matter for exclusively archivists of the past.

However I am struck by the persistent analogies with the movements and the discourses more recent, in fact contemporary. Marx denounces « reformists » of all furs, who had understood nothing of the logics of capitalist deployment. Have these disappeared from the scene? Marx denounced the lies of those who denounce the wrong doings of capitalism, but nevertheless, as the Manifesto says "in the political fight, they take completely part in all violent measures against the working class» (Marx, 1995, p. 39). Are the fascists of the XX th century and of today, the "passeist" allegedly religious movements (the Muslim Brothers, the fanatics of Hinduism and Buddhism) different?

Marx's criticisms of the competitors of Marxism, of their ideologies, his efforts to identify the social milieus of which they are the spokes persons, does not imply that for Marx, nor for us, authentic anti-capitalist movements should not be necessarily diversified in their sources of inspiration. I address the reader on this subject to some of my recent writings conceived from the perspective of the reconstruction of a new Internationale, as a condition for the efficacy of the popular struggles and visions of the future ${ }^{6}$.

\section{7.}

I shall conclude with words which follow my reading of the Manifesto.

The Manifesto is on one side the hymn to the glory of the capitalist modernity, of the dynamism which it inspires, having no parallel during the long history of civilization. But it is at the same time the swan song of this system whose own movement is nothing more than to generate chaos, like Marx has always understood and reminded. The historical reason of capitalism is no other than having produced in a brief time all the conditions, material, political, ideological and moral which impose its overcoming.

I have always shared that point of view which I believe to be that of Marx, since the Manifesto to the first epoch of the Second Internationale lived by Engels. The analyses which I proposed, concern the long ripening of the capitalism - ten centuries- and the contributions of the different regions of the world to this maturation (China, the Islamic East, Italian cities, and finally Atlantic Europe), its short zenith (the XIX th century), finally its long decline which manifests itself through two long systemic crises (the first from 1890 to 1945 , the second from the 1975 to our days). These analyses have the ambition to deepen that which was in Marx only an intuition (see Amin, 2013).

This vision of the place of capitalism in history was abandoned by the " reformist " currents within Marxism of the Second Internationale and then outside Marxism. It was substituted by a vision according to which capitalism will have accomplished its task only when it will have succeeded to homogenize the planet according to the model of its developed centres. To this persisting vision of the globalised deployment of capitalism, which is simply unrealistic since capitalism is in its nature polarizing, we oppose the vision of the transformation of the world through revolutionary processes, instead of submission to the deadly vicissitudes of the decadence of the civilization.

\footnotetext{
${ }^{6}$ See "Unité et diversité des mouvements populaires au socialisme" (in Amin, 2014; see Amin, 2017a)
} 


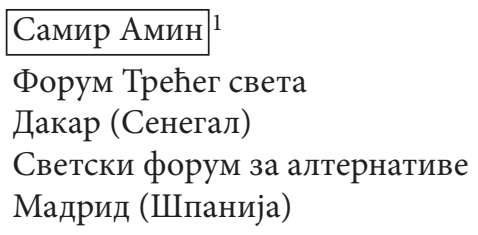

\section{КОМУНИСТИЧКИ МАНИФЕСТ, 170 ГОДИНА КАСНИЈЕ}

(Превоg In Extenso)

Сажетак: Ниједан текст написан средином деветнаестог века није очувао своју валидност до данас тако добро као Комунисииччки манифести из 1848. Може се уочити да читави параграфи текста одговарају савременој стварности, чак и више него 1848. Полазећи од премиса које једва да су биле видљиве у њихово време, Маркс и Енглес извели су закључке који су током наредних 170 година историје у потпуности потврђени. У овом чланку пружићу додатне просветљујуће примере.

Кључне речи: историјски материјализам, револуција, декаденција; глобализација хомогенизација, поларизација; империјализам; капиталистичка заграда у историји; буржоаска демократска револуција, популарна демократска револуција.

\section{1.}

Не постоји ниједан други текст написан средином деветнаестог века који је очувао своју ваљаност до данас тако добро као Манифести Комунисиичике йарйије. Читави параграфи текста одговарају савременој стварности, чак и више него 1848. Полазећи од премиса које су биле једва видљиве у њихово време, Маркс и Енгелс су извели закључке које је наредних 170 година историје у потпуности потврдило. У овом чланку пружићу додатне поучне илустрације.

Да ли су Маркс и Енгелс били инспирисани пророци, чаробњаци способни да гледају у кристалну куглу, изузетна бића у погледу своје интуиције? Не. Они су једино у своје време, као и у наше време и даље, боље од других разумели суштину онога што дефинише и одликује капитализам. Маркс је посветио свој целокупан живот да продуби ову анализу путем двоструког истраживања нове економије (полазећи од примера Енглеске) и нове политике (полазећи од примера Француске). Ја сам писао о том предмету у Окйобарској Револуцији 1917. јеgан век йосле (Amin, 2017, p. 41)2.

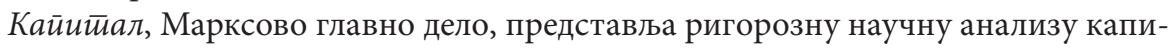
талистичког начина репродукције и капиталистичког друштва, као и тога како се

1 samir.amin@wanadoo.fr

2 у трећем поглављу, „Читајући Кайитиал”. 
они разликују од ранијих друштвених облика. Притом се упушта у срце проблема. Он непосредно разјашњава значење поопштавања размене роба између власника̂ приватне својине (а ова одлика је јединствена у савременом свету капитализма, мада је размена роба постојала и раније), конкретно појаву и преовладавање вредности и апстрактног друштвеног рада. Из те основе, Маркс нас води ка разумевању начина на који пролетерова продаја његове или њене радне снаге „човеку са новцем” осигурава производњу вишка вредности који капиталиста присваја, и који, са своје стране, представља услов за акумулацију капитала. Та доминација вредности не руководи само репродукцијом економског система капитализма; она влада сваким аспектом модерног друштвеног и политичког живота. Појам фетишизма робе указује на идеолошки механизам путем којег се изражава опште јединство друштвене репродукције.

Интелектуални и политички инструмент потврђен развојем „марксизма” показује се као најбољи за исправно предвиђање опште линије историјске еволуције капиталистичке стварности. Ниједан покушај да се та стварност промишља изван марксизма - или често против њега - није довео до упоредивих резултата. Погрешка буржоаске мисли и нарочито њене „економске науке” (коју је Маркс с добрим разлогом описао као „вулгарну”) јесте суштинска. Пошто она, наиме, није способна да разуме шта је капитализам у својој суштини, то отуђено мишљење такође није способно да замисли куда капиталистичка друштва иду. Да ли ће будућност обликовати социјалистичке револуције које ће зауставити доминацију капитала? Или ће капитализму успети да продужи своје дане, отварајући на тај начин пут ка декаденцији друштва. Буржоаска мисао игнорише та питања која поставља Манифести.

Ми доиста читамо (Marx, 1995, p. 7):

„[...] борбу коај се увек завршавала револуционарним преуређењем друштва, или заједничком пропашћу класа које су се бориле."

Ова реченица је одавно привукла моју пажњу. Полазећи од ње, прогресивно сам дошао до формулације читања крейана истиорије усредсређеног на појам неједнаког развоја света и могућих различитих процеса његовог преображаја, полазећи највероватније са његових периферија, пре него из његових центара. Такође, покушао сам да разјасним значење сваког од два модела одговора на изазове: револуционарни начин и начин декаденције.

Ја сам даље писао о том питању у књизи Класа и нација (Amin, 1979, pp. 200 $252,254-255)^{3}$.

Одлучујући да изведемо законе историјског материјализма из универзалног искуства, предложили смо алтернативну формулацију једног јединственог преткапиталистичког начина производње, трибутарног начина, којем теже сва класна друштва. Историја Запада - изградња римске антике, њена дезинтеграција, успостављање феудалне Европе, и коначно, кристализација апсолутистичких држава меркантилистичког доба - тако изражава у особеном облику исте основне тенденције које су се другде изразиле у мање дисконтинуираној изграњи потпуних, трибутарних држава, међу којима је Кина типичан израз. Ропски начин производње

\footnotetext{
3 Поглавље „Револуција или декаденција”.
} 
није универзалан у нашем читању историје, као што су то трибутарни и капиталистички начин; он је особен и појављује се искључиво у вези са ширењем робних односа. Поред тога, феудални начин је примитиван, непотпуни облик трубутарног начина.

Ова хипотеза гледа на успостављање и каснију дезинтеграцију Рима, као преурањени покушај успостављања трубутарног облика. Ниво развоја производних снага није захтевао центализацију на нивоу Римске империје. Први неуспели покушај је тако пропраћен принудним прелазом путем феудалне фрагментације, на основу које је централизација поново успостављена у оквиру апсолутистичких монархија Запада. Једино се тада начин производње на Западу приближио потпуном трибутарном моделу. Поред тога, једино с почетком овог ступња, ниво развоја производних снага на Западу достигао је онај у потпуном трибутарном начину империјалне Кине, а то несумњиво није пука коинциденција.

Заосталост Запада, изражена у распаду Рима и феудалној фрагментацији, дала му је историјску предност. Доиста, комбинација специфичних елемената античког трибутарног начина и варварских комуналних начина, одликовали су феудализам и дали су Западу његову флексибилност. То објашњава брзину којом је Европа прошла свеобухватни трибутарни начин, брзо превазилазећи ниво развоја производних снага Истока, који је сустигла и прешла у капитализам. Та флексибилност и брзина представљале су контраст с релативно крутом и спором еволуцијом целовитог трибутарног начина на Истоку.

Несумњиво римски „Западни случај” није једини пример абортиране трибутарне конструкције. Можемо да идентификујемо најмање три друга случаја те врсте, сваки са својим властитим специфичним условима: визанииијско-арайскоойомански случај, индијски случај и моніолски случај. У сваком од тих примера, покушаји успостављања трибутарног система централизације били су предалеко од захтева развоја производних снага да би били чврсто успостављени. У сваком од тих случајева, облици централизације били су вероватно особене комбинације државе, парафеудалних и робних начина. У Исламској држави, на пример, робна централизација играла је одлучујућу улогу. Сукцесивне неуспехе у Индији треба довести у везу са садржајем хинду-идеологије, коју сам контрастирао са конфучијанизмом. Што се тиче централизације Џингис Кана, она је, као што знамо, била изузетно краткотрајна.

Савремени империјалистички систем је такође систем централизације суфицита на светском нивоу. Та централизација је деловала на основу фундаменталних закона капиталистичког начина и у условима доминације над преткапиталистичким начинима подређене периферије. Формулисао сам закон акумулације капитала на светском нивоу као облик изражавања закона вредности који делује на овом нивоу. Империјалистички систем за централизацију вредности одликује убрзавање акумулације и развој производних снага у центру система, док је њихов развој на периферији заустављен и деформисан. Развој и неразвијеност су две стране истог новчића.

Само људи праве своју историју. Ни животиње ни неживи објекти не контролишу властити развој, они су му подређени. Појам праксе је својствен друштву, као израз синтезе детерминизма и људске интервенције. Дијалектички однос базе и 
надградње је такође својствен друштву и нема паралеле у природи. Тај однос није једносмеран. Надградња није пуки одраз потреба базе. Да је то случај, друштво би увек било отуђено и не би било могуће да се сагледа како би оно себе могло да ослободи.

То је разлог због којег предлажемо да разликујемо два квалитативно друкчија типа преласка из једног начина производње у други. Уколико се тај прелаз одвија несвесно, или са отуђеном свешћу, то јест уколико идеологија која утиче на класе њима не дозвољава да контролишу процес промене, овај процес изгледа као да делује на начин аналоган природним променама, док идеологија постаје део ове природе. За ту врсту прелаза ми користимо израз „модел декаденције”. С друге стране, уколико идеологија успева да понуди укупне и реалне димензије ове жељене промене, и само онда, ми можемо да говоримо о револуцији.

Буржоаска мисао мора да игнорише та питања да би била у стању да мисли о капитализму као о националном систему за целокупно будуће време, да би била у стању да мисли о „крају историје”.

\section{2.}

Маркс и Енгелс, напротив, снажно сугеришу, од времена Манифести $a$, да капитализам сачињава само кратку заграду у историји човечанства. Капиталистички начин производње, међутим, у њихово време није превазилазио Енглеску, Белгију и мали регион северне Француске, као и западни део Пруске Вестфалије. У осталим регионима целокупне Европе, ништа слично није постојало. Упркос томе, Маркс је већ замишљао да ће се социјалистичка револуција ускоро догодити у Европи. То очекивање зрачи из сваког реда Манифестй.

Маркс свакако није знао у којој земљи ће револуција почети. У Енглеској, јединој земљи која је већ напредовала у капитализму? Не. Маркс није мислио да је то могуће осим у случају да се енглески пролетаријат ослободи од својег сврставања уз буржоазију у подршци колонизације Ирске. У Француској, мада мање напредној у изразима капиталистичког развоја, али више у изразима политичке зрелости својег народа, наслеђене из њене Велике револуције? Можда. Париска комуна (1871) је потврдила ову слутњу. Енгелс је пуно очекивао од „назадне” Немачке: пролетерска револуција и буржоаска револуција могле би овде заједно да се одвијају. У вези с тим Манифести истиче следеће:

„На Немачку обраћају комунисти своју главну пажљу зато што Немачка стоји уочи буржоаске револуције и зато што она врши овај преврат под напреднијим условима европске цивилизације уопште и са много развијенијим пролетаријатом него у XVII и Француска у XVIII столећу, те, према томе, зато што немачка буржоазска револуција може да буде само непосредна предигра пролетерске револуције" (Marx, 1995, p. 54).

То се није догодило: уједињење под принудом реакционарне Прусије, политичка осредњост немачке буржоазије и њен кукавичлук омогућили су да тријумфује национализам маргинализујући народну побуну. При крају живота, Маркс је скренуо свој поглед у смеру Русије, за коју је очекивао да би могла да се ангажује на револуционарном путу и о томе сведочи његова кореспонденција са Вером Зазулич. 
Маркс је, дакле, интуитивно сматрао да би револуционарна трансформација могла да почне полазећи с периферије система, од „слабе карике” у каснијем језику Лењина. Маркс, међутим, није у своје време извео све закључке који су се наметали у том погледу. Било је неопходно да се сачека да историја напредује до двадесетог века, да би, са Лењином и Маом, могли да се виде комунисти који су постали способни да замисле нову стратегију квалификовану као „изградња социјализма у једној земљи”. То је неприкладан израз, којем ја претпостављам дугачку парафразу: „неједнако напредовање на дугом путу социјалистичког прелаза, локализовано у неким земљама које стратегија доминантног империјализма изолује и с којима се трајно и оштро бори".

Дебата која се односи на тај проблем повезана је са дугом историјом прелаза на социјализам у смеру комунизма и ка универзалном обухвату тог покрета; она поставља читаву серију питања која се тичу преображаја пролетаријата из класе по себи у класу за себе, услова и последица капиталистичке глобализације, места сељаштва у дугој транзицији, различитости израза антикапиталистичке мисли. Све су то питања којима ћу се бавити у наредном одељку.

\section{3.}

Маркс је више од било ког другог разумео да капитализам има мисију да овлада светом. Писао је о њему у време када је то освајање било далеко од довршења. Размотрио је ову мисију од њених почетака, од отрића Америке које је устоличило прелаз од три века меркантилизма на крајњи пуни облик капитализма.

Он је написао у Манифестй:

„ Крупна индустрија створила је светско тржиште, које је било припремљено открићем Америке [...] Буржоазија је експлоатацијом светског тржишта дала космополитски карактер производњи и потрошњи свих земаља" (Marx, 1995, p. 11).

Маркс је поздравио ову глобализацију, нови феномен у историји човечанства. Бројни делови у Манифестич сведоче о овоме. На пример ми читамо:

„ Где год је дошла на власт, буржоазија је разорила све феудалне, патријахалне и идиличне односе... " (Marx, 1995, p. 10).

И:

„Буржоазија је село потчинила господству града [...] и тако знатан део становништва отела од идиотизма сеоског живота. Као што је село учинила зависним од града, тако је она варварске и полуварварске земље учинила зависнима од цивилизованих земаља, сељачке народе од буржоаских народа, Исток од Запада..." (Marx, 1995, p. 13).

Речи су јасне. Маркс никада није био оријентисан на прошлост, жалећи за добрим старим временима. Он је увек изражавао модерно становиште, до тога да изгледа као европоцентриста. Прешао је дуг пут у том смеру. Па, ипак, није ли варваризацију сеоског рада заменио градски рад који није био ништа мање осакаћујући за пролетере? Маркс не ингорише градско сиромаштво које је пратило капиталистичко ширење.

Да ли је Маркс из доба Манифестиа тачно одмерио политичке последице уништавања сељаштва у Европи самој, и још више, у колонизованим земљама? 
Вратићу се тим питањима у непосредној вези с неједнаким карактером светског развоја капитализма.

Маркс и Енгелс у Манифестиу и даље не знају да светско ширење капитализма није онакво како су га замишљали, да хомогенизује, то јест да освојеном Истоку пружа шансу да изађе из ћорсокака у који га је историја затворила и да се усклади са сликом Западних земаља, „цивилизованих” нација, то јест индустријализованих земаља. Неколико каснијих Марксових текстова представљају колонизацију Индије у утешном светлу. Маркс је касније променио своје мишљење. Те алузије, пре него систематски разрађена аргументација, сведоче о деструктивним последицама колонијалног освајања. Маркс постепено постаје свестан онога што ја називам „неједнаким развојем”. То је систематска конструкција контраста између доминантних центара и доминираних периферија, а тиме и немогућности да се „сустигне” унутар оквира капиталистичке глобализације (у ствари империјалистичке по својој природи), и путем капиталистичких средстава.

У овом погледу рекао сам да уколико би било могуће да се „сустигне” у оквиру капиталистичке глобализације, никаква политичка, друштвена или идеолошка снага не би била у стању да јој се успешно супротстави.

У погледу питања „отварања” Кине, Маркс у Манифесӣу пише: „јефтине цене њених роба јесу тешка ариљерија којом она руши све кинеске зидове, којом она и најупорнију мржњу варвара против странаца присиљава на капитулацију” (Marx, 1995, p. 12).

Ми знамо да се ово отварање није одвијало на описани начин: топови британске морнарице били су ти који су „отворили” Кину. Кинески производи су често били компетитивнији од западних. Такође, знамо да није енглеска напредна индустрија била та која је омогућила успешну доминацију над Индијом (опет, индијски текстил је био бољег квалитета од енглеског). Напротив, доминација над Индијом (и организовано уништавање индијске индустрије) омогућила је Великој Британији хегемонију у капиталистичком систему деветнаестог века.

Међутим, старији Маркс научио је како да напусти европоцентризам из времена своје младости. Он је знао како да промени своје мишљење у светлу еволуције света.

У 1848. години, Маркс и Енгелс су стога са великом сигурношћу претпостављали да ће доћи до једне или више социјалистичких револуција у Европи њиховог времена, потврђујући тиме да капитализам представља једино кратку заграду у историји. Чињенице су ускоро потврдиле ту претпоставку. Париска комуна (1871) била је прва социјалистичка револуција. Међутим, то је била истовремено и последња револуција остварена у развијеној капиталистичкој земљи. Са успостављањем Друге интернационале Енгелс није изгубио наду у нови револуционарни напредак, посебно у Немачкој. Историја је показала да није био у праву. Издаја Друге интернационале, 1914. године, међутим, није требало никога да изненади. Поред њиховог реформистичког усмерења, сврставање радничких партија у читавој Европи тог времена са експанзионистичким империјалистичким и колонијалним политикама њихових буржоазија, указивало је да нема шта пуно да се очекује од партија Друге интернационале. Линија фронта за преображај света померила се према Истоку, ка Русији, 1917. године, и Кини. Свакако, Маркс то није йреgвиgео: али његови каснији 
текстови дозвољавају нам да претпоставимо да он вероватно не би био изненађен руском револуцијом.

С друге стране, у погледу Кине, Маркс је сматрао да је на дневном реду буржоаска револуција. Након интервенције европских сила и одговора на побуну Боксера, он је подсетио да ће наредни пут кад европске армије покушају да уђу у Кину, бити изненађене истакнутом таблом на којој ће писати: „Пажња, улазите у буржоаску Републику Кину!”. Куоминтанг из револуције 1911. године, на челу са Сун Јат Сеном, такође је размишљао, попут Маркса, проглашавајући буржоаску републику Кину. Међутим, Сун није успео нити да порази снаге старог режима, чији су господари рата поново заузели територију, нити да потисне доминацију империјалистичких снага, нарочито Јапана. Лутања КМТ Чанг Каи Шека потврдила су Лењиново и Маово становиште да више нема простора за једну аутентичну бужоаску револуцију, зато што је наша епоха епоха социјалистичке револуције. Као што Фебруарска револуција у Русији није имала будућност, пошто није била у стању да победи стари режим, призивајући стога Октобарску револуцију, Кинеска револуција 1911. призвала је револуцију Маових комуниста, једино способну да одговори на очекивања ослобођења које је истовремено национално и социјално.

Тако је то била Русија, „слаба карика” система, која је иницирала другу социјалистичку револуцију после Париске комуне. Руски Октобар, међутим, није био подржан, него нападан од стране европског радничког покрета. Роза Луксембург је користила опоре изразе за скретања европског радничког покрета. Она говори о њиховом „недостатку”, о „неспособности немачког пролетаријата да схвати своју историјску мисију”, о „издаји” (Luxemburg, 2017, p. 10, 5, 9).

Ја сам са своје стране предложио анализу тог повлачења радничке класе на развијеном Западу, напуштања властите револуционарне традиције деветнаестог века, стављајући акценат на разарајуће последице империјалистичког карактера светског ширења капитализма и користи које је целина одговарајућих друштава (а не само њихове буржоазије) извукла из њиховог доминантног положаја. Стога сам сматрао да је неопходно да целокупно поглавље у оквиру мог читања универзалног значаја Октобарске револуције (Amin, 2017) ${ }^{4}$ посветим анализи развоја који је европску радничку класу довео до одрицања од своје историјске мисије, казано у изразима Розе Луксембург. Читаоца упућујем на тај текст.

4.

Револуционарни напредак на дугачком путу социјалистичке или комунистичке транзиције отуда ће вероватно да започне искључиво у друштвима на периферији светског система, управо у земљама у којима би авангарда разумела да није могуће да се он „достигне” путем интеграције у капиталистичку глобализацију. Из тог разлога „нешто друго треба да се учини”, то јест да се настави у правцу преласка социјалистичког типа. Лењин и Мао су изразили то убеђење проглашавајући да наше време више није период буржоаских револуција, већ да је од тада почела епоха социјалистичких револуција.

\footnotetext{
4 Четврто поглавље „Револуције и контрареволуције од 1917. до 2017”.
} 
Тај закључак води другом закључку: социјалистичка транзиција ће се нужно догађати „у једној земљи”, која ће поред тога да остане „изолована” услед противнапада светског империјализма. Нема алтернативе; неће бити „светске револуције”. Стога ће нације и државе укључене на овом путу бити суочене са двоструким изазовом: да се одупру перманентном рату (топлом и хладном) који воде империјалистичке снаге и да успешно повезују сељачку већину у напредовању на путу ка социјализму. Како ни Манифести, тако ни Маркс ни Енгелс нису били у позицији да кажу нешто о тим питањима. То припада живом марксизму да учини уместо њих.

Та размишљања ме доводе до процене разматрања сељаштва које су Маркс и Енгелс развили у Манифестй. Маркс и Енгелс су ситуирани у оквиру свог времена које је и даље било време незавршених буржоаских револуција у самој Европи. У том контексту, ми читамо у Манифестиу: „На том ступњу, дакле, пролетаријат не води борбу против својих непријатеља, већ против непријатеља својих непријатеља, против остатака апсолутне монархије, против земљопоседника [...] свака победа која се тако извојује јесте победа буржоазије” (Marx, 1995, p. 18).

Буржоаска револуција, међутим, дала је земљу сељацима, као што је показано нарочито на примеру Француске. Стога је сељаштво у својој великој већини постало савезник буржоазије у оквиру блока бранитеља свете природе приватне својине и постало је непријатељ пролетаријата.

Пренос центра гравитације социјалистичког преображаја света, међутим, одлазак из доминантних империјалистичких земаља у доминиране периферије, радикално преобликује сељачко питање. Упркос свему, револуционарни напреци постају могући у условима друштава која су и даље остала великим делом сељачка, уколико социјалистичке авангарде јесу способне да примене стратегије које интегришу већину сељаштва у оквир борбеног блока против империјалистичког капитализма.

\section{5.}

Маркс и Енгелс никад нису веровали, ни у време објавивања Манифести $a$, а ни касније, у спонтани револуционарни потенцијал радничке класе; стога су „Владајуће идеје неког времена биле су увек само идеје владајуће класе” (Marx, 1995, str. 34). Услед те чињенице, радници, као и остали, усвајају идеологију „такмичења”, тог камена-темељца функционисања капиталистичког друштва и стога „организовање пролетера у класу, а тиме у политичку партију, бива опет сваког тренутка разбијано конкуренцијом међу самим радницима” (Marx, 1995, p. 34).

Отуда преображај пролетаријата из класе по себи у класу за себе имплицира активну интервенцију комунистичке авангарде: „у пракси оног дела радничких партија свих земаља који је најдолучнији, који стално гура даље, они у теријском погледу имају то преимућство над осталом масом пролетаријата што разумеју услове, ток и опште резултате пролетерског покрета. " (Marx, 1995, p. 25).

Афирмација неизбежне улоге авангарде не значи за Маркса заговарање „једне партије”. У Манифестич читамо:„Комунисти нису нека посебна партија према другим радничким партијама [...] Они не постављају никакве посебне принципе у које би хтели да укалупе пролетерски покрет. ” (Marx, 1995, p. 25). 
У каснијој замисли како би требало да изгледа пролетерска интернационала, Маркс је такође сматрао да је неопходно да се у њу укључе све партије и струје мишљења и делања које доиста имају народну и радничку публику. Прва инернационала укључивала је у своје чланство француске бланкисте, немачке ласаловце, енглеске синдикалисте, прудонисте, анархисте, бакуњинисте. Маркс сигурно није штедео од своје критике, често оштре, многе од својих партнера. Могло би се рећи и да је вероватно силовитост тих конфликтних дебата у корену кратког живота те Прве интернационале. Било како било, та организација ипак је била прва школа за образовање будућих кадрова ангажованих у борби против капитализма.

Та опажања воде до питања о улози партије и комуниста.

Прво питање тиче се односа између комунистичког покрета и „нације”. У $\mathrm{Ma}$ нифестй можемо да прочитамо: „Радници немају отаџбине. Њима се не може узети оно што немају. Али како пролетаријат прво мора да освоји политичку власт, да се подигне до националне класе, да се сам конституише као нација, то је и он још националан, мада никако у смислу буржоазије”; „Борба пролетаријата против буржазије, мада није у својој основи национална, задобија, међутим, национални облик" (Marx, 1995, p. 33).

У капиталистичком свету пролетери не деле национализам њихове земље; они не припадају тој нацији. Разлог томе је што у буржоаском свету једина функција национализма јесте да пружи легитимност, с једне стране, експлоатацији радника дате земље и, с друге стране, борби буржоазије против њених иностраних такмаца, као и испуњењу њене империјалистичке амбиције. С победом евентуалне социјалистичке револуције, мећутим, све би се променило. Оно што сам горе истакао тиче се прве дугачке фазе социјалистичке тразниције у друштвима на периферији. То, такође, изражава поштовање за неопходну разноликост предузетих путева. Тако појам крајњег циља комунизма појачава значај националне разноликости пролетерских нација. Манифести је већ формулисао идеју да је комунизам изграђен на различитости индивидуа, колектива и нација. Солидарност не искључује слободан развој свих, већ га имплицира. Комунизам је антитеза капитализма, који, мада проповеда „индивидуализам”, производи у ствари, кроз такмичење клонове форматиране доминацијом капитала.

У наставку ћу цитирати, у овом контексту, оно што сам написао у својој књизи о Окииобарској револуичиј 1917, век касније:

„Подржавање или одбацивање националног суверенитета изазива озбиљне неспоразуме догод класни садржај стратегије у оквиру које он делује још није идентификован. Доминантни друштвени блок у капиталистичким друштвима увек замишља национални суверенитет као инструмент промовисања својих класних интереса, то јест капиталистичког израбљивања домаћег рада и, истовремено, учвршћивања својег положаја у глобалном систему. Данас, у контексту глобализованог либералног система којим доминирају финансијски монополи Тријаде (САД, ЕУ, Јапан) национални суверенитет представља инструмент који дозвољава владајућим класама да очувају своје такмичарске позиције у оквиру система. Влада САД нуди најјаснији пример ове сталне праксе: суверенитет се замишља као искључиви резерват монополног капитала САД, а у складу са овим је и да је у оквиру САД националном законодавству дат приоритет у односу на међународни закон. То је такође била пракса 
европских империјалистичих сила у прошлости и наставља да буде пракса главних европских држава у оквиру Европске уније” (Amin, 2017, pp. 83-85) 5 .

Имајући ово на уму, разумемо зашто је национални дискурс који хвали врлине суверенитета, скривајући класне интересе у служби којих делује, одувек био неприхватљив за све оне који бране производне класе.

Па ипак, не би требало да сведемо одбрану суверенитета на тај модалитет буржоаског национализма. Одбрана суверенитета није мање одлучна за одбрану народске алтернативе на дугом путу у социјализам. Суверенитет чак представља неизбежан услов за напредовање у том смеру. Разлог за то је чињеница да глобални поредак (као и његов подглобални европски поредак) никада неће бити преображен одозго, путем колективне одлуке владајућих класа. Напредак у том смислу увек је резултат неједнаког напредовања борби од једне земље до друге. Трансформација глобалног система (или подсистема Европске уније) јесте производ тих промена које се одвијају у оквиру различитих држава. Те промене, са своје стране, модификују међународну равнотеже снага између држава. Држава нација остаје једини оквир за одвијање одлучујуће борбе која у крајњој линији преобликује свет.

Народи периферије система, који је по својој природи поларизирајући, имају дугачко искуство тог позитивног прогресивног национализма који је антиимперијалистички, одбацује глобални поредак који намећу центри и стога је потенцијално антикапиталистички. Кажем само потенцијално, зато што тај национализам може да инспирише илузију о могућој изградњи националног капиталистичког поретка способног да сустигне национални капитализам владајућих центара. Национализам на периферији јесте прогресиван једино под условом да остане антиимперијалистички, то јест да је данас у сукобу са глобалним либералним поретком. Сваки други национализам (који у овом случају јесте само фасада), који прихвата глобални либерални поредак, представља инструмент локалних владајућих класа. Оне имају за циљ да учествују у израбљивању својих народа и уз пут и других слабијих партнера, делујући тиме као подимперијалистичке силе.

Конфузија између та два опречна појма националног суверенитета и стога одбацивање сваког национализма, поништава могућност кретања изван глобалног либералног поретка. На несрећу, левица - у Европи и другде - често прави ову забуну.

Друга напомена тиче се сегментације радничке класе, упркос „поједностављивању” друштва повезаном са напредовањем капитализма, које је евоцирано у Манифестй:

„Наша епоха, епоха буржоазије, поседује, међутим, следећу особену одлику: она је поједноставила класне антагонизме. Друштво као целина се све више располућује на два велика непријатељска табора, у две велике класе које се непосредно суочавају - на буржоазија и пролетаријат" (Marx, 1995, p. 7).

То двоструко кретање поопштавања положаја пролетера и, истовремено, сегментирање света радника - данас је далеко видљивије него што је то био случај 1848, када се једва појављивало.

Током продуженог двадесетог века, до наших дана, били смо сведоци генерализације без преседана услова пролетаријата. Данас је у центрима готово укуп-

5 Дискутовао сам о том питању специфично за Европу у Имйлозији савременої кайийализма (Amin, 2013), поглавље 4. 
но становништво сведено на статус најамника који продају своју радну снагу. На периферијама пак сељаштво је интегрисано више него икада до сада у оквиру трговачких мрежа које су збрисале његов статус независног произвођача, претварајући га у потчињеног подуговарача, сведеног, у ствари, на статус продаваца своје радне снаге.

Тај развој повезан је с процесом осиромашења. „Радник постаје паупер, а пауперизам се развија још брже него становништво и богатство." (Marx, 1995, p. 23).

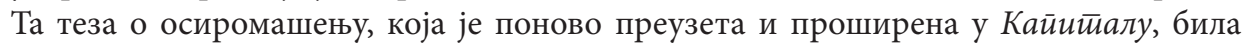
је предмет саркастичних критика вулгарних економиста. Па ипак, на нивоу светског капиталистичког система, на једином нивоу који пружа пуни смисао анализи стварности, та пауперизација је значајно више видљива и стварна него што је Маркс замишљао. С друге стране, и паралелно с тим, капиталистичке снаге успеле су да ослабе опасност коју представља поопштена пролетаријанизација путем примењивања систематских стратегија које циљају на сегментирање радничке класе на свим нивоима, од националног, до међународног.

\section{6.}

Трећи одељак Манифестиа, назван „Социјалистичка и комунистичка литература", могао би савременом читаоцу да се учини као да доиста припада прошлости. Маркс и Енгелс нуде нам у њему коментаре који се тичу историјских тема и њихове интелектуалне производе који припадају њиховом времену. Заборављена, та питања изгледају данас као тема искључиво за архиваре прошлости.

Ја сам, међутим, под снажним утиском сталних аналогија с недавним покретима и дискурсима који су, у ствари, савремени. Маркс денунцира „реформисте” свих боја, који ништа нису разумели о логици капиталистичког развоја. Да ли су они нестали са сцене? Маркс критикује лажи оних који нападају зла капиталиизма, али ипак, као што пише у Манифестиу „у политичкој борби, они у целини учествују у свим насилним мерама против радничке класе” (Marx, 1995, p. 39). Да ли су фашисти двадесетог века и ови данашњи, „прошлости” окренути наводно верски покрети (муслиманска браћа, фанатици хиндуизма и будизма) битно различити?

Марксова критика такмаца марксизма, њихове идеологије, његови напори да идентификује друштвене средине којих су они гласноговорници, не значи да за Маркca, нити за нас, аутентични антикапиталистики покрети не би нужно требало да буду разнолики у својим изворима инспирације. Ја упућујем читаоца у вези са овом темом на моје текстове новијег датума замишљене из перспективе реконструкције нове Интернационале, као услова за ефикасност популарне борбе и визија будућности ${ }^{6}$.

7.

Закључићу речима које следе моје читање Манифестиа.

Манифести је, с једне стране, химна величанствености капиталистичке модерности, динамичности коју она инспирише, која није имала премца током дуге историје цивилизације. Али она је истовремено лабуgова йесма система чије вла-

6 В. „единство и различитост народних покрета ка социјализму” (у Amin, 2014; в. Amin, 2017a) 
стито кретање није ништа више него стварање хаоса, као што је то Маркс увек разумевао и на то подсећао. Историјски разлог капитализма није ниједан други до да произведе, за кратко време, све услове, материјалне, политичке, идеолошке и моралне, који намећу његово превазилажење.

Увек сам делио то гледиште за које верујем да је и Марксово, од Манифесий до прве епохе Друге интернационале коју је доживео Енгелс. Анализе које сам ја предложио тичу се дугог дозревања капитализма - десет векова - и доприноса различитих региона света том сазревању (Кина, Исламски Исток, Италијански градови, и на крају Атлантска Европа), његовог краткотрајног зенита (деветнаести век), и, коначно, његовог дугорочног опадања које се манифестује преко две дуге системске кризе (прве од 1890. до 1945, и друге од 1975. до наших дана). Те анализе имају амбицију да продубе оно шо је код Маркса била само интуиција (уп. Amin, 2013).

Ову визију места капитализма у историји напустиле су „реформистичке” струје у оквиру марксизма Друге инернационале, а након тога, и изван марксизма. Она је замењена визијом према којој ће капитализам испунити свој задатак само кад успе да хомогенизује планету према моделу развијених центара. Тој упорној визији глобализованог распоређивања капитализма, која је просто нереалистична с обзиром да капитализам, по својој природи, јесте поларизујући, ми супротстављамо визију трансформације света кроз револуционарни процес, уместо подређивања смртоносним неизвесностима декаденције цивилизација.

\section{REFERENCES / ЛИТЕРАТУРA}

Amin, S. (1980). Class and Nation. New York: Monthly Review Press

Amin, S. (2013). The implosion of contemporary capitalism. New York: Monthly Review Press

Amin S. (2014). Egypte, nassérisme et communisme. Paris: Les Indes Savantes

Amin, S (2017). October 1917 Revolution, a century later. Montreal (CA): Daraja Press

Amin S. (2017a). L'indispensable reconstruction de l'Internationale des travailleurs et des peoples. Available at http://www.grila.org/index_grila.php?gri=ref\&ref=200036 \&lang $=\mathrm{fr}$

Luxemburg, R. (2017). The Russian Revolution. Paris, Edition l'Aube [In French]

Marx, K. (1995). Manifesto of the Communist Party (translated by Laura Lafargue). Paris: Le Temps des Cerises [In French] 